RÖVID IRÉN - ERÁT DÁVID - FÜZÉR KATALIN ${ }^{1}$

\title{
A PÁRKAPCSOLAT, A GYERMEKNEVELÉS ÉS A TÁRSADALMI TŐKE SZEREPE A SZUBJEKTÍV JÓLLÉT ALAKULÁSÁBAN
}

https://doi.org/10.18030/socio.hu.2021.1.62

\section{Absztrakt}

Az egyének szubjektív jóllétére ható kapcsolati tényezőket vizsgáló elemzésünket a globális COVID-19 járvány elleni védekezésben világszerte alkalmazott azon fizikai interakciókat korlátozó társadalmi gyakorlatok inspirálták, amelyeknek célja egyrészt minél inkább az egy háztartásban élők körére szűkíteni a kapcsolattartást, másrészt érdemben nehezíteni a társadalmi interakciókat a társadalmi tőke mindhárom típusában. Az elemzés alapjául szolgáló nagymintás adatfelvétel a 2016-os mikrocenzus ( $N=2$ millió 724 ezer), ami lehetővé teszi, hogy számot adjuk mind a párkapcsolati-gyermeknevelési státusszal megragadható kapcsolati tényezők, mind a társadalmi tőke három típusában érintett kapcsolati tényezők szerepéről a szubjektív jóllét kognitív dimenziójának, az életelégedettségnek az alakulásában a 20-49 évesek körében. Elemzésünk kiindulópontját az a tény adja, hogy az életelégedettség összefügg azzal, párkapcsolatban él-e valaki (és milyen jellegúben), illetve nevel-e gyermeket a háztartásában (Rövid 2020). Elemzésünk középpontjában az a kérdés áll, hogy mennyiben érinti hasonlóképpen vagy különbözőképpen a párkapcsolati-gyermeknevelési státusz szerint elkülönülő hat háztartástípusba tartozók életelégedettségét a háztartáson kívüli fizikai kapcsolattartás. Eredményeink szerint a járványhelyzetben is érintett kapcsolati tényezők életelégedettségre gyakorolt hatása hasonlóan alakul egyrészt a szinglik és a gyermeküket egyedül nevelők körében, másrészt a párkapcsolatban élők körében, gyermeknevelési státusztól függetlenül. A kapcsolati tényezők közül tehát a párkapcsolatnak kiemelt jelentősége van a szubjektív jóllét alakulásban, ami a párkapcsolatok minőségének, sérülékenységének mintázataira is ráirányítja a figyelmet (Erát 2020). Elemzésünk alapján hipotéziseket fogalmazzuk meg a további kutatások számára. Átfogó hipotézisünk szerint a járványhelyzet a háztartáson kívüli kapcsolati tényezőkre gyakorolt korlátozó hatásán keresztül összességében jelentős mértékben, azonban párkapcsolati-gyermeknevelési státusz szerint differenciáltan rontja az életelégedettséget a 20-49 évesek körében.

Kulcsszavak: szubjektív jóllét, életelégedettség, párkapcsolat, gyermeknevelés, társadalmi tőke, COVID-19

1 Rövid Irén PhD Elemző, Központi Statisztikai Hivatal. Erát Dávid, MA Egyetemi tanársegéd, Pécsi Tudományegyetem, Bölcsészet- és Társadalomtudományi Kar, Társadalom- és Médiatudományi Intézet, Szociológia Tanszék. Doktorjelölt, PTE BTK Demográfia és Szociológia Doktori Iskola. Füzér Katalin, PhD. Egyetemi docens, Pécsi Tudományegyetem, Bölcsészet- és Társadalomtudományi Kar, Társadalom- és Médiatudományi Intézet, Szociológia Tanszék. 
THE ROLE OF PARTNERSHIP, PARENTING AND SOCIAL CAPITAL IN WELLBEING

\section{ABSTRACT}

Our analysis of the relational factors involved in subjective wellbeing was inspired by global social practices of restricting physical interactions in the fight against the COVID-19 pandemic. Restrictive measures are supposed to constrain interactions to the household and at the same hinder social intercourse that normally occurs as a feature of the three types of social capital. The empirical basis of the analysis is the large-sample Hungarian micro census of 2016 ( $N=2724000$ ) which makes it possible to examine how life satisfaction, i.e. the cognitive dimension of subjective wellbeing among 20-49-year-olds connects on the one hand to the relational factors represented by partnership-parenting status, and on the other hand to the relational factors implicated in the three types of social capital. The starting point of our analysis is evidence concerning the connection in the Hungarian context between life satisfaction, partnership status and parenting status, respectively. (Rövid 2020). The central question of our analysis is to what extent the life satisfaction level of individuals living in households differentiated by partnership and parenting status is connected to their practice of physical social interactions beyond the household. Our results show that relational factors, implicated in the pandemic, play a similar role in the case of singles and single parents, and also among those living in partnership, irrespective of parental status. We find that partnership has an outstanding role in subjective wellbeing, which highlights the significance of both the quality as well as the vulnerability of partnerships (Erát 2020). These results also provide the grounds for hypotheses that can be explored in further research: our overall hypothesis is that the pandemic, through its restrictive effect on relational factors beyond the household, substantially diminishes life satisfaction among 20-49 year-olds, with significant differences according to the partnership and parenting status of individuals.

Keywords: subjective wellbeing, life satisfaction, partnership, parenting, social capital, COVID-19 


\title{
A PÁRKAPCSOLAT, A GYERMEKNEVELÉS ÉS A TÁRSADALMI TŐKE SZEREPE
}

\author{
A SZUBJEKTÍV JÓLLÉT ALAKULÁSÁBAN
}

\section{BEVEZETÉS²}

A szubjektív jóllét kapcsolati tényezők mentén történő vizsgálatának különös aktualitást ad a COVID-19 globális járványhelyzet. A védekezés különféle társadalmi kapcsolatokra gyakorolt hatását számos kutatás vizsgálta már, amelyek alapján megállapíthatjuk, hogy a háztartáson kívüli, személyes jelenléttel megvalósított kapcsolattartás világszerte visszaszorul a fizikai interakciókat korlátozó társadalmi gyakorlatok nyomán (TóthHudácskó 2020, Teslya et al. 2020, Scala et al. 2020, Vokó-Pitter 2020, Goumenou et al. 2020). A korlátozásokat azért alkalmazzák, mert a COVID-19, más világjárványokat okozó fertőzésekhez hasonlóan, az emberek közötti fizikai interakciók során intenzíven terjed. Így egyes kutatások egyenesen a védekezés sikerességének egyik indikátoraként tekintenek a személyes jelenléttel megvalósított kapcsolatok visszaszorulásának különféle mutatószámaira (Merkely et al. 2020, Röst et al. 2020, Galvan, Quarleri 2020, McKee 2020). A fizikai kapcsolattartás volumenének csökkenéséhez nagymértékben hozzájárul a home office gyakorlata és az online oktatás, de a napi mobilitást egy sor korlátozó intézkedés is csökkenti a szolgáltatásokat nyújtó intézmények bezárásától, vagy nyitva tartásának szúkítésétől kezdve a kijárási tilalomig (Merkely et al. 2020). ${ }^{3}$

A kutatások egy másik csoportja a háztartáson kívüli társadalmi kapcsolatok mellett a háztartáson belüli kapcsolatok átalakulását is fókuszba helyezi a járványhelyzet vizsgálatában. A járványhelyzetben gyermeket nevelő családok helyzetével foglalkozó kutatások (Prime et al. 2020, Russell et al. 2020, Gregor et al. 2020, Möhring et al. 2020, Gregor-Kováts 2020) mellett a párkapcsolatok alakulását is számos elemzés vizsgálja (pl. Pietromonaco-Overall 2020, Settersen et al. 2020).

A járványhelyzet társadalmi hatásainak megértéséhez kutatásunk azzal járul hozzá, hogy megalapozott hipotéziseket fogalmaz meg a kapcsolati tényezők és az életelégedettség összefüggésére vonatkozóan. Arra vállalkozunk, hogy a párkapcsolatok és a gyermeknevelés kapcsolati tényezői mentén kialakított háztartástípusok szerint tanulmányozzuk a járványhelyzetben világszerte alkalmazott, fizikai interakciókat korlátozó társadalmi gyakorlatok által közvetlenül érintett kapcsolati tényezők közül a megkötő, az összekötő és az összekapcsoló társadalmi tőke egy-egy megnyilvánulásának szerepét a szubjektív jóllét kognitív dimenziójának, az életelégedettségnek az alakulásában.

2 A szerzők kutatómunkáját támogatta Füzér Katalin és Erát Dávid esetében a TKP2020-IKA-08 számú projekt, amely a Nemzeti Kutatási Fejlesztési és Innovációs Alapból biztosított támogatással, a Tématerületi Kiválósági Program 2020 (2020-4.1.1-TKP2020) pályázati program finanszírozásában valósult meg; Rövid Irén esetében az EFOP-3.6.3-VEKOP-16-2017-00007 Tehetségből fiatal kutató - A kutatói életpályát támogató tevékenységek a felsőoktatásban. A jelen dokumentum a Központi Statisztikai Hivatal 2016. évi mikrocenzus adatállományainak a felhasználásával készült. A számítások és az azokból levont következtetések kizárólag Rövid Irén, Erát Dávid és Füzér Katalin, mint szerzők szellemi termékei.

3 A fizikai kapcsolattartás visszaszorulásával párhuzamosan az online interakciók számos területen szisztematikusan előtérbe kerülnek (Füzér 2020): a munkavégzés és az oktatás mellett a fogyasztás, a szolgáltatások igénybevétele, a szabadidő eltöltése és a családi kapcsolattartás (Szalma, Rékai 2020) során is előnyökkel járó opcióként, sőt bizonyos esetekben egyenesen kényszerként valósul meg az életvilág mediatizálása (Berger 2020) a digitalizációs átalakulás ipar 4.0 kereteit jóval túllépő folyamatában. 


\section{ELMÉLETI KERETEK, KUTATÁSI ELŐZMÉNYEK}

Számos tanulmány mutatott már rá arra, hogy szubjektív jóllétünk függ attól, hogy párkapcsolatban, azaz házasságban vagy élettársi kapcsolatban, vagy éppen egyedül élünk-e. Ugyanis azok, akik tartós párkapcsolatban, házasságban élnek, boldogabbak, elégedettebbek az életükkel, mint azok, akik pár nélkül, egyedül élnek (Veenhoven 1984, Utasi 2008, Cargan 1981, DePaulo-Morris 2005, Diener et al. 1999, Haller-Hadler 2006, Hertel et al. 2007, Hradil 1995, 2003, Ho 2015, Shapiro-Keyes 2008, Verbakel 2012). Továbbá a gyermek léte, nem léte a háztartásban is jelentős szerepet tölt be az életelégedettség alakulásában (Veenhoven 1984, Nelson-Coffey 2019, Balbo-Arpino 2016, Molnár-Kapitány 2014, Radó 2019).

Más kutatások arra a következtetésre jutottak, hogy a szubjektív jóllét és a családi állapot között nem található jelentős összefüggés (Hertel et al. 2007, DePaulo-Morris 2005, Czibere 2017). Ha a házasok jellemzőit ugyanis például azokhoz a szinglikéhez viszonyítanánk, akik még sosem kötöttek házasságot, vagyis nőtlen, hajadon családi állapotúak voltak, akkor a két csoport értékei nem térnének el olyan élesen egymástól (DePauloMorris 2005). Ebben az is szerepet játszhat, hogy bár a házasokra jellemzőtől némileg elmaradt, de a szinglik is igen magasra értékelték a szubjektiv jóllétüket. A barátokkal, a testvérekkel, a szülőkkel és gyermekekkel való törődés, jó kapcsolat is pozitív hatással van a szinglik jóllétére (Hertel et al. 2007, Haller-Hadler 2006, CockrumWhite 1985). Verbakel (2012) a „jelenlegi párkapcsolati státuszt” („current partnership status” Verbakel 2012: 206) a törvényes családi állapotnál alkalmasabbnak találta a szubjektív jóllét vizsgálatára. Kutatási eredményei szerint a házasok a legelégedettebbek az életükkel, őket követik az élettársak, a látogató párkapcsolatban (LAT) élők, a szinglik, az özvegyek, végül pedig az elváltak.

Az életelégedettséget vizsgáló tanulmányunk kiindulópontját a nagy elemszámú adatállományon, a 2016-os mikrocenzuson alapuló kutatási eredmények adják, melyek alapján elmondható, hogy számos társadalmi-demográfiai tényező szorosan összefügg az életelégedettséggel (Rövid 2020). ${ }^{4}$ A nem, az életkor, az iskolai végzettség, valamint a településtípus mellett a párkapcsolati-gyermeknevelési státusz szerepével kapcsolatban született eredményekre támaszkodik jelen elemzésünk. A korábbi vizsgálat azt találta, hogy a nők valamelyest elégedettebbek az életükkel, az életkor előrehaladtával csökken az életelégedettség, a felsőfokú végzettségűekre pedig az ennél alacsonyabb végzettséggel rendelkezőknél magasabb fokú elégedettség jellemző. A településlejtő jelensége is visszaköszönt az eredményekben: Budapesthez képest a többi településtípusban élők kevésbé voltak elégedettek az életükkel. A párkapcsolati-gyermeknevelési státuszt illetően pedig a következő eredmények születtek: a gyermektelen házasok bizonyultak a legelégedettebbnek, őket követték a gyermekes házasok, az életelégedettségi rangsor végén pedig a gyermeküket egyedül nevelő szülők álltak. Számszerű eredményeink szerint leginkább a házastársukkal élő gyermektelenek $(7,16)$ elégedettek az életükkel, őket követik a gyermeket nevelő házasok (7,11), a gyermektelen élettársak $(6,99)$, a szinglik $(6,77)$, a gyermeket nevelő élettársak $(6,66)$, végül pedig a gyermeküket egyedül nevelő szülők $(6,01)$. Az eredményekből többek között arra következtethetünk, hogy a párkapcsolat léte és formája szorosabb kapcsolatban áll az életelégedettséggel, mint a gyermeknevelés. A témával foglalkozó nemzetközi kutatásokhoz hasonlóan (Cargan 1981, DePaulo-Morris 2005, Diener et al. 1999, Haller-Hadler 2006, Hertel et al. 2007, Hradil 1995, 2003, Ho 2015, Shapiro-Keyes 2008, Verbakel 2012, Veenhoven 1984, Stutzer 2006) saját kutatási eredményeink is megerősítették, hogy a házasságban élők elégedettebbek leginkább az életükkel.

Vizsgálatunk fókuszában nem a teljes népesség, hanem a magánháztartásban élő 20-49 évesek álltak: a gyermeket nevelő, nem nevelő házasságban vagy élettársi kapcsolatban élők, a gyermeküket egyedül nevelő

4 Az egész bekezdés Rövid Irén (2020) doktori disszertációján alapul. 
szülők, valamint a tartós párkapcsolat és gyermek nélkül élő szinglik. Azonban mivel a Verbakel (2012) nyomán lehatárolt párkapcsolati-gyermeknevelési státusz segítségével a párkapcsolat mellett a gyermeknevelés hatására is következtetni kívántunk, ezért fontosnak tartottuk, hogy egy olyan szúkebb korcsoportot vizsgáljunk, akik a 2016-os mikrocenzus eszmei időpontjában gyermeket neveltek, vagy életkorukból adódóan már szülővé válhattak volna. Azzal, hogy elemzésünkben a 20-49 évesekre összpontosítunk, egy olyan életszakaszt vizsgálhattunk, amely a nők szempontjából is még reproduktívnak tekinthető. Bár a 2016. évi mikrocenzus pillanatfelvétel, vagyis az abból származó adatok azt az állapotot tükrözik, amely a felvétel eszmei időpontjában jellemezte a magyar társadalmat, mégis relevánsnak tartjuk jelen vizsgálatunk szempontjából, hiszen az elemzésbe bevont szempontok időbeli változásáról feltételezhetjük, hogy összefüggéseiket tekintve néhány év távlatában nem jelentősek. Így elemzésünk érvényes megállapításokat tesz lehetővé arról, hogy az élettel való elégedettségre milyen hatást gyakorolnak a járványhelyzetben is érintett kapcsolati tényezők az egyes párkapcsolati-gyermeknevelési státusz alapján képzett csoportok körében.

A szubjektív jólétet a párkapcsolaton és a gyermeknevelésen kívül számos más kapcsolati tényező is befolyásolja. Utasi Ágnes (2008) magyar társadalmat vizsgáló elemzésében bemutatta, hogy a családi, rokoni, valamint a baráti kapcsolatok mellett a kisközösségi kapcsolatok, a spontán társas készségen alapuló szerveződésekbe való bekapcsolódás is szorosan (bár nem, iskolai végzettség és korcsoportok szerint differenciáltan) összefügg az életelégedettséggel. Utasi kutatása a szubjektív jóllétre ható kapcsolati tényezők körében vizsgálta továbbá a közéletiséget is, amit annak igényeként azonosított, hogy a szúkebb, önkéntes szerepvállaláson túlmenő társadalmi közegre is hatással bíró tevékenységet ambicionáljon a válaszadó. Eredményei szerint „a tanulmányaikat már befejezett, családot alapított, forráserős [26-35 éves] kisgyermekesek” (2008: 52) csoportjára a legjellemzőbb a közéletiség iránti igény és körükben ennek a kapcsolati tényezőnek kiemelkedő szerepe van az életelégedettség alakulásában.

A társadalmi tőke irodalmában is fontos szerepe van a szubjektiv jóllét problémájának (Bjørnskov 2003, 2008, Sarracino 2010, Klein 2013). A kutatások a társadalmi tőke mindhárom dimenziójában, a bizalom, az interakciós normák, és a kapcsolathálók esetében is azonosítják a szubjektív jólléttel, illetve az életelégedettséggel való összefüggést. Portela és szerzőtársai (2013) összefoglaló tanulmánya a jólléttel legszorosabban összefüggő tényezők között említi a szúkebben értelmezett társadalmi kapcsolatok mellett a civil szervezeti aktivitást, valamint a politikai intézményekhez való bizalmi kötődést. A társadalmi tőke irodalmában egyre elfogadottabb megfogalmazással (Füzér 2015) a megkötő társadalmi tőkét megjelenítő családi és rokoni kapcsolatok mellett az összekötő társadalmi tóke megnyilvánulását, az önkéntes szervezeti aktivitást, valamint az összekapcsoló társadalmi tőkeként értelmezett közéleti szubjektív kompetenciát emelik ki Portela és szerzőtársai (2013) az életelégedettségre ható kapcsolati tényezők közül. 
A KAPCSOLATI TÉNYEZŐK SZEREPE AZ ÉLETELÉGEDETTSÉG ALAKULÁSÁBAN A 2016-OS MIKROCENZUSON: ADATOK, MÓDSZEREK

Elemzésünkhöz a KSH által a szegedi kutatószobában rendelkezésünkre bocsátott 2016-os mikrocenzus adatait használtuk fel, mely egy két népszámlálás között megvalósuló nagymintás reprezentatív adatfelvétel. A mikrocenzus tekinthető egyfajta "kis népszámlálásnak” is, hiszen az adatbázis a magyar háztartások 10\%-os mintáját tartalmazza, Így a népesség főbb társadalmi és területi jellemzői mellett alkalmas az életkörülmények számos tényezőjének, köztük a kapcsolati tényezőknek, valamint azt élettel való elégedettségnek a vizsgálatára is. Ennélfogva adataink lehetőséget nyújtanak arra, hogy a járványhelyzetben alkalmazott, fizikai interakciókat korlátozó gyakorlatok által érintett kapcsolati tényezőket és azok életelégedettséggel való összefüggését elemezzük.

Az elemzés során többváltozós lineáris regressziós modelleket készítettünk, amelyek függő változója az egyén szubjektiv élettel való elégedettsége. A szubjektiv életelégedettséget a mikrocenzusban a válaszadók egy 11 fokú skálán értékelték, melyben a 0 jelentette az „egyáltalán nem elégedett”, 10 pedig a „teljes mértékben elégedett" választ.

A mikrocenzus állományában rendelkezésre álló változók közül összesen további hat olyan kapcsolati tényezőt megragadó változót hoztunk létre, amelyekre a kutatások szerint a járványhelyzet közvetlen hatást gyakorol. A társadalmi tőke és a szubjektív életelégedettség összefüggését vizsgáló szakirodalommal összhangban két változóval mérjük a megkötő társadalmi tőkét: a rokonok, illetve barátok látogatásának gyakoriságával, meIyet a válaszadók egy ötfokú skálán jelezhettek. Elemzésünkben ezt a skálát egyszerúsítettük egy-egy dichotóm változóra, mely megkülönbözteti azon személyeket, akik legfeljebb időnként látogatják rokonaikat, barátaikat azoktól, akik ennél gyakrabban járnak össze barátaikkal, illetve rokonaikkal. A szakirodalmi előzmények alapján feltételeztük, hogy a szubjektív jólléttel a közeli kapcsolatok mellett az egyén civil szervezetekben megnyilvánuló közösségi aktivitása, az összekötő társadalmi tőke egyik megnyilvánulása is összefügg. A közösségi aktivitást egy összevont, 0-4-ig terjedő skálával tettünk mérhetővé, egy-egy pontot adva az egyének minden aktív tagságáért a kérdőívben szereplő önkéntes szervezetekben (pl. sport, szociális, egyházi). Végül, külön változóval mértük az összekapcsoló társadalmi tőke megnyilvánulásaként az egyén szubjektív közéleti kompetenciáját, azaz véleményét arról, hogy milyen mértékben képes a lakóhelyét, települését, vagy az országot érintő kérdések befolyásolására, amit ismét összevont kategóriákkal érzékeltettünk a modelljeinkben.

A társadalmi tóke három típusát megragadó változók mellett elemzésünkben támaszkodtunk a Verbakel (2012) nyomán kialakított, a korábbi kutatómunkában (Rövid 2020) is alkalmazott párkapcsolati, gyermeknevelési státuszt jelölő változóra is („current partnership status”, Verbakel 2012: 206). Összesen hat kategóriát alakítottunk ki: (1) a házas- és élettárs nélkül élő, gyermeküket egyedül nevelő szülők; (2) házastársukkal együtt élő, gyermeket nevelők; (3) élettársi kapcsolatban élő, gyermeket nevelők; (4) házastársukkal élő gyermektelenek; (5) élettársi kapcsolatban élő gyermektelenek; valamint (6) a szinglik. A párkapcsolatban élők esetében csak azokat vontuk be a vizsgálatba, akik együtt éltek házas- vagy élettársukkal. Azok számítottak gyermeket nevelőknek, akiknek élt a háztartásában legalább egy, 25 éven aluli, nőtlen, hajadon családi állapotú, gazdasági aktivitását tekintve eltartott, egyéb inaktív vagy munkanélküli gyermek. A szinglik közé pedig azokat a személyeket soroltuk családi állapottól függetlenül, akiknek nem volt se tartós párkapcsolata (ebben az esetben külön, vagy együtt élő élettársuk), se élve született vagy nevelt gyermeke, és egyedül élt a háztartásban.

A kapcsolati tényezőket megragadó független változók mellett természetesen egyéb magyarázó változókat is beemeltünk a modellekbe. Minden esetben a válaszadó neme, életkora, lakóhelye, legmagasabb iskolai végzettsége, valamint az általános bizalom szintje tényezőinek kontrolálása biztosította, hogy elkerüljük a hibás 
következtetéseket. Összességében az eredményeket hét, hasonló felépítésű többváltozós lineáris regressziós modell segítségével ismertetjük. Elsőként a teljes modellt mutatjuk be, majd ezután a hatásokat a párkapcsolati és gyereknevelési státusz egyes kategóriái szerint külön-külön is megvizsgáljuk.

\section{EREDMÉNYEK}

A kapcsolati tényezők életelégedettséggel való összefüggését elsőként a teljes mintán vizsgáltuk meg, az eredményeket az 1. táblázatban foglaltuk össze. Mivel a mikrocenzus rendkívül nagy mintán kínál elemzési lehetőséget, így a hatások értelmezése során az empirikus elemzésekben gyakran (hibásan) megjelenő egyszerű szignifikáns/nem szignifikáns értelmezés mellett figyelembe kellett venni a koefficiensek nagyságát és konfidencia intervallumát, elkerülve a nagy mintából fakadó téves következtetéseket.

A teljes modell eredményeinek értelmezését a kontrollváltozókkal kezdve megállapíthatjuk, hogy az élettel való elégedettség az életkorral csökken $(B=-0,035)$, valamint a fóvároshoz képest csak a nagyközségben és községben élők mutatnak valamivel kisebb mértékű elégedettséget $(B=-0,149)$. A végzettség esetében jól láthatóan kirajzolódik az alacsonyabb végzettség negatív hatása: a felsőfokú végzettséget szerzettekhez képest a középfokú végzettségűek ( $B=-0,388$ ) elégedetlenebben az életükkel, ami jóval nagyobb mértéket ölt a legfeljebb nyolc általánossal rendelkezők $(B=-1,164)$ körében. Végül, azon személyek, akik általánosságban jobban bíznak az emberekben elégedettebbek életükkel a modell szerint $(B=0,264)$. A kontrollváltozók közül a válaszadó nemének nem volt figyelemre méltó hatása.

Rátérve az elemzés központi magyarázó változóira, a járványhelyzetben is érintett társadalmi tőke tényezőket mérni kívánó változók a várt hatásokat tárták fel. A modell szerint azokhoz képest, akik gyakran látogatják rokonaikat, az azokkal ritkán találkozók elégedetlenebben életükkel $(B=-0,294)$ és hasonló, valamivel gyengébb hatás mutatható ki a barátok ritka látogatása esetén is $(B=-0,218)$. A közeli kapcsolatok mellett a közösségi szervezeti aktivitás hatása is kimutatható volt: minél több önkéntes szervezetben volt aktív tag valaki, annál inkább elégedett volt az életével $(B=0,218)$. Az összekapcsoló társadalmi tőkét jelző három változó az egyén szubjektív kompetenciáját mérte fel, azaz az arra vonatkozó véleményét, hogy milyen mértékben képes a környezetét (lakóhelyét, települését, illetve az országot) érintő kérdéseket befolyásolni. Jól láthatóan az egyének élettel való elégedettségét kiemelten a lakóhelyüket érintő kérdések befolyásolása határozza meg: e szerint azon személyek, akik „is-is” választ adtak a kérdésre $(B=-0,479)$, és kiemelten azok, akik szerint nincs befolyásuk ( $B=-0,637$ ), jóval elégedetlenebbnek mutatkoztak a magukat befolyással rendelkezőknek gondolókhoz képest. A közvetlen lakóhelytől távolodva, a település, valamint az ország kérdései esetében a hatások már gyengébbek.

Végül a párkapcsolati-gyermeknevelési státusz változóit vontuk be. A gyermeket nevelő házasokhoz képest mindössze a gyermektelen házas válaszadók bizonyultak észrevehetően elégedettebbnek életükkel, ugyanakkor a többi kategóriánál látható hatások erőssége érdekes összefüggésekre utal. Az eredményekből látható, hogy a gyermeket nevelő házasokhoz képest a szinglik $(B=-0,879)$ és még ennél is nagyobb mértékben az egyedülálló szülők ( $B=-0,963)$ elégedetlenebbek az életükkel. Ugyan alacsonyabb elégedetlenséget találunk a gyermekes $(B=-0,228)$ és a gyermektelen ( $B=-0,247)$ élettársi kapcsolatban élő személyek esetén is, az öszszes kategóriát figyelembe véve a meghatározó töréspont a párkapcsolatban élők és a párkapcsolat nélküliek között látható. 
1. táblázat. Lineáris regresszió az élettel való szubjektív elégedettségre

\begin{tabular}{|c|c|c|c|c|c|}
\hline & \multicolumn{5}{|c|}{ Teljes } \\
\hline & \multirow{2}{*}{\multicolumn{2}{|c|}{ B }} & \multirow{3}{*}{$\begin{array}{c}\text { S.E. } \\
0,011\end{array}$} & \multicolumn{2}{|c|}{ K. I. (95\%) } \\
\hline & & & & \multirow{2}{*}{$\begin{array}{c}\text { Alsó } \\
8,245\end{array}$} & \multirow{2}{*}{$\begin{array}{c}\text { Felső } \\
8,288\end{array}$} \\
\hline Konstans & 8,267 & $* * *$ & & & \\
\hline Nő (Ref.: Férfiak) & 0,017 & $* * *$ & 0,003 & 0,012 & 0,022 \\
\hline Életkor & $-0,035$ & $* * *$ & 0,000 & $-0,035$ & $-0,034$ \\
\hline \multicolumn{6}{|l|}{ Lakóhely (Ref.: Budapest) } \\
\hline Megyeszékhely, M.J.V. & $-0,089$ & $* * *$ & 0,004 & $-0,096$ & $-0,081$ \\
\hline Város & $-0,056$ & $* * *$ & 0,004 & $-0,064$ & $-0,049$ \\
\hline Nagyközség, község & $-0,149$ & $* * *$ & 0,004 & $-0,157$ & $-0,141$ \\
\hline \multicolumn{6}{|l|}{ Végzettség (Ref.: Felsőfokú) } \\
\hline Legfeljebb befejezett általános iskola & $-1,164$ & $* * *$ & 0,005 & $-1,173$ & $-1,155$ \\
\hline Középfokú & $-0,388$ & $* * *$ & 0,003 & $-0,394$ & $-0,382$ \\
\hline Ritka rokonlátogatás (Ref.: Gyakori) & $-0,294$ & $* * *$ & 0,003 & $-0,301$ & $-0,288$ \\
\hline Ritka barátlátogatás (Ref.: Gyakori) & $-0,218$ & $* * *$ & 0,003 & $-0,224$ & $-0,211$ \\
\hline Civil szervezeti aktivitás skála & 0,218 & $* * *$ & 0,003 & 0,213 & 0,223 \\
\hline Bizalom skála & 0,264 & $* * *$ & 0,001 & 0,263 & 0,266 \\
\hline \multicolumn{6}{|c|}{ Képes lakóhelyet érintő kérdések befolyásolására (Ref.: Inkább - teljesen egyetért) } \\
\hline Egyáltalán nem - inkább nem ért egyet & $-0,637$ & $* * *$ & 0,004 & $-0,645$ & $-0,630$ \\
\hline is-is & $-0,479$ & $* * *$ & 0,004 & $-0,487$ & $-0,472$ \\
\hline \multicolumn{6}{|c|}{ Képes települését érintő kérdések befolyásolására (Ref.: Inkább - teljesen egyetért) } \\
\hline Egyáltalán nem - inkább nem ért egyet & $-0,479$ & $* * *$ & 0,004 & $-0,487$ & $-0,472$ \\
\hline is-is & 0,094 & $* * *$ & 0,007 & 0,081 & 0,106 \\
\hline \multicolumn{6}{|c|}{ Képes az országot érintő kérdések befolyásolására (Ref.: Inkább - teljesen egyetért) } \\
\hline Egyáltalán nem - inkább nem ért egyet & 0,057 & $* * *$ & 0,007 & 0,044 & 0,070 \\
\hline is-is & $-0,143$ & $* * *$ & 0,007 & $-0,157$ & $-0,130$ \\
\hline \multicolumn{6}{|c|}{ Párkapcsolati státusz (Ref.: Házas, gyermekkel) } \\
\hline Élettársi kapcsolat, gyermekkel & $-0,228$ & $* * *$ & 0,004 & $-0,235$ & $-0,220$ \\
\hline Egyedülálló szülő & $-0,963$ & $* * *$ & 0,005 & $-0,973$ & $-0,953$ \\
\hline Házas, gyermektelen & $-0,057$ & $* * *$ & 0,005 & $-0,066$ & $-0,048$ \\
\hline Élettársi kapcsolat, gyermektelen & $-0,247$ & $* * *$ & 0,004 & $-0,256$ & $-0,239$ \\
\hline Szingli, gyermektelen & $-0,879$ & $* * *$ & 0,005 & $-0,888$ & $-0,870$ \\
\hline Elemszám (súlyozott) & \multicolumn{5}{|c|}{2604205} \\
\hline F-statisztika & \multicolumn{5}{|c|}{$27276,926 * * *$} \\
\hline Korrigált R-négyzet & \multicolumn{5}{|c|}{0,19} \\
\hline
\end{tabular}

Forrás: Mikrocenzus 2016.

Megjegyzés: * $p<0,05 ; * * p<0,01 ; * * *<0,001$.

Összességében a teljes modell alapján elmondható, hogy az egyén élettel való elégedettsége a kiemelt magyarázó változók közül erős összefüggésben van a rokonok és barátok látogatásával, az önkéntes szervezetekben kifejtett aktivitással, valamint a közvetlen környezet befolyásolásának képességével. Emellett fontos szerepet kap a párkapcsolati-gyermeknevelési státusz két kategóriája is: a szinglik, illetve a gyermeküket egyedül nevelő szülők jelentősen elégedetlenebbek életükkel a teljes modell eredményei alapján. 


\section{2. táblázat.}

Lineáris regresszió az élettel való szubjektiv elégedettségre párkapcsolati és gyereknevelési státusz szerint

\begin{tabular}{|c|c|c|c|c|c|c|c|c|c|c|c|c|c|c|c|}
\hline & \multicolumn{5}{|c|}{ Házas, gyermeket nevelők } & \multicolumn{5}{|c|}{$\begin{array}{c}\text { Élettársi kapcsolat, gyermeket } \\
\text { nevelők }\end{array}$} & \multicolumn{5}{|c|}{ Házas, gyermektelenek } \\
\hline & \multirow{2}{*}{\multicolumn{2}{|c|}{ B }} & \multirow{3}{*}{$\begin{array}{c}\text { S.E. } \\
0,005\end{array}$} & \multicolumn{2}{|c|}{ K. I. (95\%) } & \multirow{2}{*}{\multicolumn{2}{|c|}{ B }} & \multirow{3}{*}{$\begin{array}{c}\text { S.E. } \\
0,009\end{array}$} & \multicolumn{2}{|c|}{ K. I. (95\%) } & \multirow{2}{*}{\multicolumn{2}{|c|}{$B$}} & \multirow{3}{*}{$\begin{array}{c}\text { S.E. } \\
0,010\end{array}$} & \multicolumn{2}{|c|}{ K. I. $(95 \%)$} \\
\hline & & & & Alsó & Felső & & & & Alsó & Felső & & & & Alsó & Felső \\
\hline $\begin{array}{l}\text { Ritka rokonláto- } \\
\text { gatás } \\
\text { (Ref.: Gyakori) }\end{array}$ & $-0,400$ & $* * *$ & & $-0,409$ & $-0,390$ & $-0,369$ & $* * *$ & & $-0,387$ & $-0,351$ & $-0,217$ & $* * *$ & & $-0,237$ & $-0,197$ \\
\hline $\begin{array}{l}\text { Ritka barátláto- } \\
\text { gatás } \\
\text { (Ref.: Gyakori) }\end{array}$ & $-0,076$ & $* * *$ & 0,005 & $-0,086$ & $-0,066$ & $-0,235$ & $* * *$ & 0,010 & $-0,254$ & $-0,217$ & $-0,191$ & $* * *$ & 0,011 & $-0,212$ & $-0,170$ \\
\hline $\begin{array}{l}\text { Civil szervezeti } \\
\text { aktivitás skála }\end{array}$ & 0,237 & $* * *$ & 0,004 & 0,230 & 0,244 & 0,326 & $* * *$ & 0,009 & 0,308 & 0,344 & 0,118 & $* * *$ & 0,008 & 0,103 & 0,133 \\
\hline \multicolumn{16}{|c|}{ Képes lakóhelyet érintô kérdések befolyásolására (Ref.: Inkább - teljesen egyetért) } \\
\hline $\begin{array}{l}\text { Egyáltalán nem } \\
\text { - inkább nem ért } \\
\text { egyet }\end{array}$ & $-0,523$ & $* * *$ & 0,006 & $-0,534$ & $-0,512$ & $-0,704$ & $* * *$ & 0,010 & $-0,724$ & $-0,684$ & $-0,855$ & $* * *$ & 0,012 & $-0,879$ & $-0,831$ \\
\hline is-is & $-0,469$ & $* * *$ & 0,006 & $-0,480$ & $-0,457$ & $-0,506$ & $* * *$ & 0,011 & $-0,527$ & $-0,484$ & $-0,485$ & $* * *$ & 0,013 & $-0,510$ & $-0,461$ \\
\hline \multicolumn{16}{|c|}{ Képes települését érintő kérdések befolyásolására (Ref.: Inkább - teljesen egyetért) } \\
\hline $\begin{array}{l}\text { Egyáltalán nem } \\
\text { - inkább nem ért } \\
\text { egyet }\end{array}$ & 0,116 & $* * *$ & 0,009 & 0,097 & 0,134 & $-0,049$ & * & 0,019 & $-0,085$ & $-0,012$ & 0,100 & $* * *$ & 0,021 & 0,059 & 0,142 \\
\hline is-is & 0,116 & $* * *$ & 0,009 & 0,098 & 0,134 & 0,001 & & 0,019 & $-0,036$ & 0,038 & $-0,144$ & $* * *$ & 0,021 & $-0,185$ & $-0,103$ \\
\hline \multicolumn{16}{|c|}{ Képes az országot érintő kérdések befolyásolására (Ref.: Inkább - teljesen egyetért) } \\
\hline $\begin{array}{l}\text { Egyáltalán nem } \\
\text { - inkább nem ért } \\
\text { egyet }\end{array}$ & $-0,240$ & $* * *$ & 0,010 & $-0,259$ & $-0,220$ & 0,274 & $* * *$ & 0,020 & 0,234 & 0,313 & $-0,072$ & $*$ & 0,022 & $-0,116$ & $-0,028$ \\
\hline is-is & $-0,122$ & $* * *$ & 0,010 & $-0,142$ & $-0,101$ & 0,366 & $* * *$ & 0,021 & 0,325 & 0,407 & 0,031 & & 0,023 & $-0,014$ & 0,077 \\
\hline $\begin{array}{l}\text { Elemszám } \\
\text { (súlyozott) }\end{array}$ & \multicolumn{5}{|c|}{1185422} & \multicolumn{5}{|c|}{408818} & \multicolumn{5}{|c|}{231516} \\
\hline F-statisztika & \multicolumn{5}{|c|}{$12817,721 * * *$} & \multicolumn{5}{|c|}{$4476,022^{* * *}$} & \multicolumn{5}{|c|}{$3324,081^{* * *}$} \\
\hline $\begin{array}{l}\text { Korrigált } \\
\text { R-négyzet }\end{array}$ & \multicolumn{5}{|c|}{0,16} & \multicolumn{5}{|c|}{0,16} & \multicolumn{5}{|c|}{0,20} \\
\hline
\end{tabular}

Forrás: Mikrocenzus 2016.

Megjegyzés: Terjedelmi okok miatt csak a modell fö hipotézisek számára releváns részei szerepelnek a táblában. A teljes modellek a függelékben láthatók. Az eredmények a következő változók kontrollja mellett mutatkoztak: nem, életkor, lakó-

hely, végzettség, általános bizalom.

$* p<0,05 ; * * p<0,01 ; * * p<0,001$. 
3. táblázat. Lineáris regresszió az élettel való szubjektiv elégedettségre párkapcsolati és gyereknevelési státusz szerint (folytatás)

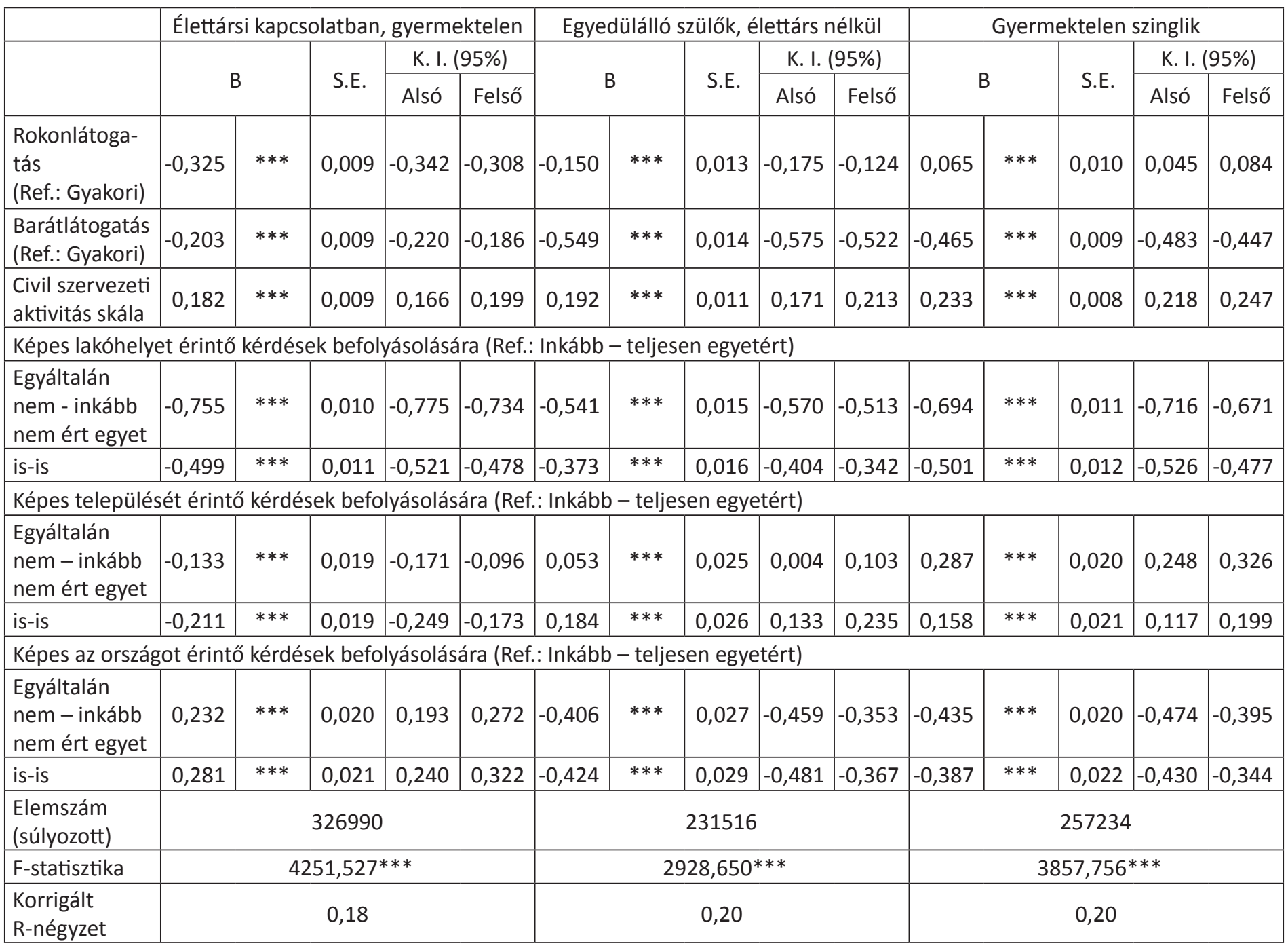

Forrás: Mikrocenzus 2016.

Megjegyzés: Terjedelmi okok miatt csak a modell fö hipotézisek számára releváns részei szerepelnek a táblában. A teljes modellek a függelékben láthatók. Az eredmények a következő változók kontrollja mellett mutatkoztak: nem, életkor, lakó-

hely, végzettség, általános bizalom.

* $p<0,05$; ** $p<0,01$; *** $p<0,001$. 
A járványhelyzet háztartáson kívüli fizikai kapcsolattartást korlátozó élethelyzetét a háztartás összetétele szempontjából jól megragadó párkapcsolati-gyermeknevelési státusz egyes kategóriái szerint szétbontott modellek alapján az életelégedettséggel összefüggő és a járványhelyzet által közvetlenül érintett kapcsolati tényezőket megjelenítő változókra vonatkozóan összetett kép bontakozik ki. Az értelmezés során a teljes modellhez hasonlóan hangsúlyos volt a szignifikancia mellett a koefficiensek és konfidencia intervallumok értéke is, ugyanakkor a hat modell összehasonlításának egyszerüsége kedvéért ezeket az értékeket (melyeket a 2. és a 3. tábla, valamint a Függelékben mellékelt adatok mutatnak) a szövegben nem jelöltük külön.

A rokonokkal való kapcsolattartás a legtöbb párkapcsolati-gyermeknevelési státusz csoportban fontos tényező, a gyakorihoz képest a ritka találkozás alacsonyabb élettel való elégedettséggel függ össze. Kiemelten igaz ez a gyermeket nevelő házasok esetében, de hasonlóan erős az élettársi kapcsolatban élők esetében, függetlenül attól, hogy nevelnek-e gyermeket. A hatás kisebb a gyermektelen házasoknál, de még mindig látható. Ugyanakkor egyértelmúen gyenge befolyása van a rokonlátogatásának az életelégedettség alakulására az egyedülálló szülők esetében és semmilyen értékelhető mértékű hatása nincs a szinglik körében.

A barátok látogatásának viszont éppen azon párkapcsolati-gyermeknevelési státuszban lévők esetében van nagyobb szerepe, akiknél a rokonok szerepe kisebb: kiemelten csökkenti az élettel való elégedettséget a két „kitett” csoport, a gyermeküket egyedül nevelő szülők és a gyermektelen szinglik esetén, ha barátaikkal ritkán találkoznak. Ezzel szemben a barátok látogatásának hatása elhanyagolható a gyermeket nevelő házasok esetében, míg a többi csoportnál a barátlátogatás elmaradásának hatása negatív ugyan, de jelentősége nem éri el a két „kitett” kategória, a gyermeküket egyedül nevelő szülők és a szinglik esetében tapasztalt mértéket.

Az önkéntes szervezetekben folytatott közösségi aktivitás intenzitásának csökkenése minden csoport esetében együtt járt az élettel való elégedettség romlásával. A hatások nagyjából hasonló méretűek, kivéve a gyermektelen házasok esetén, ahol gyengének mutatkozik.

A szubjektív kompetencia terepei közül a közvetlen lakóhelyet érintő közügyekkel kapcsolatos befolyás minden csoport számára fontos elem az élettel való elégedettség tekintetében. Azok, akik valamilyen mértékben nem értettek egyet azzal, hogy képesek befolyásolni a közvetlen lakóhelyüket érintő kérdéseket, elégedetlenebbek voltak az életükkel. A gyermektelen csoportokban (gyermektelen házasok és élettársak, illetve a szinglik) és az élettársi kapcsolatban gyermeket nevelők körében a legerősebb az összefüggés a szubjektiv közéleti kompetencia, valamint az életelégedettség között, és ha kevésbé intenzíven is, de egyértelműen jelen van a gyermeket nevelő házasok és a gyermeküket egyedül nevelő szülők esetében is.

A település közügyeivel kapcsolatos befolyás jelentősége már jóval kisebb az életelégedettség alakulásában az egyes párkapcsolati-gyermeknevelési státusz szerinti csoportokban. Egyedül a szinglik esetében mondható el, hogy körükben egyértelmúen csökkenti az életelégedettséget, ha nem tudnak befolyást gyakorolni a településüket érintő döntésekre.

Végül az ország közügyeire vonatkozó szubjektív kompetencia tekintetében megállapítható, hogy leginkább a gyermeküket egyedül nevelő szülők, illetve a szinglik esetében van negatív hatása az élettel való elégedettségre, ha úgy érzik, nem tudják befolyásolni az országot érintő kérdéseket. Kisebb mértékben igaz ez a gyermeket nevelő házasok esetében is, ugyanakkor meglepő eredmény, hogy az élettársi kapcsolatban élők körében (függetlenül attól, hogy nevelnek-e gyermeket) kis mértékben növeli az életelégedettséget a szubjektív kompetencia hiánya országos ügyekben. 


\section{KÖVETKEZTETÉSEK, TOVÁBBI KUTATÁSI KÉRDÉSEK}

Eredményeink alapján a párkapcsolat és a gyermeknevelés kapcsolati tényezői szerint elkülönülő élethelyzetek esetében tehát különféleképpen alakulnak az életelégedettséggel összefüggésben lévő olyan kapcsolati tényezők, amelyekre a COVID-19 járványhelyzet korlátozó intézkedései közvetlen hatást gyakorolnak. Az egyes párkapcsolati-gyermeknevelési státuszok szerinti eredményeket a következőkben lehet összefoglalni.

A házas, gyermeket nevelőkre, az elemzés legnagyobb elemszámú csoportjába tartozókra, a családcentrikusság jellemző. Körükben a rokonlátogatások ritkulása jelentősen rontja az életelégedettséget, ugyanakkor a barátlátogatásnak nincs érdemleges befolyásoló ereje. Ez arra enged következtetni, hogy a házas, gyermekes egyének számára a rokoni kapcsolatok ápolása kiemelten fontos, Így nagy a kitettségük a járványhelyzetben és nem csak a kiemelten veszélyeztetett idősebb rokonok vonatkozásában. A gyermeket nevelő házasok esetében a közösségi szervezeti aktivitás visszaszorulása is csökkenti az életelégedettséget, de ennek mértékét tekintve nem különböznek jelentősen a másféle párkapcsolati-gyermeknevelési státuszban lévőktől. A közéleti szubjektív kompetencia a házas és gyermeket nevelők körében a lakóhelyet érintő közügyek tekintetében a többi párkapcsolati-gyermeknevelési státusszal összevetésben is kiemelkedően fontos. A gyermeket nevelő házasok számára a lakóhely mellett az ország közügyei személy szerint is fontosak, de a településé már kevésbé.

Az élettársi kapcsolatban élő gyermeket nevelőkre a családi kapcsolatokon túlmutató nyitottság többféle értelemben is érvényes. Ugyan a házasokhoz hasonlóan az élettársi kapcsolatban gyermeket nevelők körében is szorosan összefügg az életelégedettség a rokonok látogatásának gyakoriságával, ugyanakkor esetükben a barátok hasonló jelentőségre tesznek szert. Ez jelenthet körükben egyfajta "többlábon állást”, ugyanakkor a járványhelyzet látogatásokat ritkító hatása egyúttal feltételezhetően nagyobb fokú kitettséget is eredményez a gyermeket nevelő élettársak számára. A tágabb társas környezet felé való nyitottabb hozzáállást mutathatja az is, hogy az élettársi kapcsolatban gyermeket nevelők esetében az életelégedettség erősen összefügg a közösségi szervezeti aktivitással, olyannyira, hogy ez az összefüggés ennél a csoportnál mutatkozott a leginkább meghatározónak. Tovább növeli a járványhelyzetnek való szubjektív jólléti kitettséget a gyermeket nevelő élettársak körében az, hogy a megkötő társadalmi tőke (rokonok, barátok) és az összekötő társadalmi tőke (közösségi szervezeti aktivitás) megnyilvánulásai mellett az összekapcsoló társadalmi tőke terén is erősen összefügg életelégedettségük a lakóhely és az ország közügyeivel kapcsolatos szubjektív kompetenciájukkal. Amennyiben romlik az élettársi kapcsolatban gyermeket nevelők szubjektív közéleti kompetenciája, azaz kevésbé vannak arról meggyőződve, hogy képesek befolyásolni a lakóhelyüket és az országot érintő döntéseket, akkor az előnytelenül befolyásolja életelégedettségüket is.

A gyermektelen házasokat a járványhelyzet kapcsolati tényezőket befolyásoló hatása feltételezhetően nem érinti olyan erőteljesen. Körükben ugyan a rokonok mellett a baráti látogatásoknak is van némi szerepe az életelégedettség alakulásában, azonban az összefüggés kevésbé erős. Ugyanezen következtetést támogatja a közösségi aktivitás hatásának gyengesége is: az összes párkapcsolati-gyermeknevelési státusz közül esetükben a leggyengébb a különböző közösségi szervezetekben való aktív részvétel pozitív hatása és ezzel a legkisebb a kitettségük is ezen a területen. A szubjektív közéleti kompetencia tekintetében egyedül a lakóhely közügyei fontosak a gyermektelen házasok számára, ugyanakkor az elégedettségük változása indifferens a települési és egyedülálló módon az országos közügyekre való hatás vonatkozásában. Összességében egyfajta befelé fordulásra utalnak az eredmények: a házaspár egymásra és közvetlen környezetére fókuszál, a társas kapcsolatok tágabb dimenziói, a szervezeti aktivitás és a közügyek jórészt háttérbe szorulnak. 
Az élettársi kapcsolatban élő gyermektelenek a szubjektív elégedettséget befolyásoló kapcsolati tényezők tekintetében leginkább azokra hasonlítanak, akik szintén élettársai kapcsolatban élnek, de gyermeket is nevelnek, így összességében erősen kitettek a kapcsolatokat érintő hatásoknak. A gyermeket nem nevelő élettársak körében is fontos szerepet kapnak a barátok és rokonok is az életelégedettség alakulásában, ugyanakkor a közösségi aktivitás fontossága mellett annak hatása valamivel kisebb. Szubjektív közéleti kompetenciájukat az jellemzi, hogy nemcsak a lakóhely és az ország közügyei, hanem a településük közügyei is személy szerint fontosak számukra - utóbbi tekintetében még a gyermeket nevelő élettársaknál is nyitottabbak és egyúttal feltételezhetően kitettebbek is a járványhelyzetnek.

A párkapcsolat nélkül élők körében, azaz a gyermeküket egyedül nevelő szülők és a szinglik esetében az életelégedettség alakulásában a kapcsolati tényezők hasonló mintázatait fedezhetjük fel. A barátok szerepe kiemelkedően nagy, míg a rokonok szerepe sokkal kisebb, mint a párkapcsolatban élő másik négy státuszba tartozók esetében. A közösségi szervezeti aktivitásnak, valamint a lakóhely és az ország közügyeihez való kapcsolódásnak a többi csoporthoz hasonló, áltagos szerepe van a párkapcsolat nélkül élők életelégedettségének alakulásában.

A járványhelyzet társadalmi hatásainak elemzéséhez kutatásunk azzal járult hozzá, hogy a párkapcsolatok és a gyermeknevelés kapcsolati tényezői segítségével kialakított háztartástípusok szerint tanulmányoztuk a járványhelyzetben világszerte alkalmazott, fizikai interakciókat korlátozó társadalmi gyakorlatok által közvetlenül érintett kapcsolati tényezők közül a megkötő, az összekötő és az összekapcsoló társadalmi tőke egy-egy megnyilvánulásának szerepét a szubjektív jóllét kognitív dimenziójának, az életelégedettségnek az alakulásában. Eredményeink alapján megfogalmazható az a hipotézis, hogy a járványhelyzet kapcsolati tényezőkre gyakorolt hatása révén összességében jelentősen rontja az életelégedettséget a vizsgált 20-49 évesek körében. A további kutatások számára azonban azt a speciálisabb hipotézist is megfogalmazhatjuk, hogy ez a hatás jelentősen differenciált aszerint, hogy valaki párkapcsolatban él-e, illetve hogy nevel-e gyermeket, azaz hogy milyen szerkezetű háztartásban éli meg a járványhelyzetet. Így a járványhelyzetnek a kapcsolati tényezőkön keresztül való kitettség szempontjából a párkapcsolat nélkül élő szinglik és a gyermeküket egyedül nevelők, valamint az élettársi kapcsolatban élők számára valószínúleg a veszteség, a bizonytalanság, a bezártság és az elszigeteltség érzése is hozzájárul a járványhelyzet megéléséhez, hiszen a vizsgálatba bevont megkötő, összekötő és összekapcsoló társadalmi tőke készletük szerkezetének törékenysége miatt egyúttal sérülékenyebbek is. Az életvilág digitalizációjának vizsgálata körükben lehet a legrelevánsabb az eredményeink szerint feltárt kitettségük alapján megfogalmazott hipotézis szerint: bizonyára keresik és meg is találják azokat az online megoldásokat, amelyek segítik őket a járványhelyzettel való megküzdésben. 


\section{HIVATKOZÁSOK}

Balbo, N. - Arpino, B. (2016) The role of family orientations in shaping the effect of fertility on subjective well-being: a propensity score matching approach. Demography, 53(4), 955-978. https://doi.org/10.1007/s13524-016-0480-z

Berger, V. (2020) Phenomenology of online spaces: interpreting late modern spatialities. Human Studies. 43, 603-626. https://doi.org/10.1007/s10746-020-09545-4

Bian, Y. - Miao, X. - Lu, X. - Ma, X. - Guo, X. (2020) The Emergence of a COVID-19 Related Social Capital: The Case of China. International Journal of Sociology, 50(5), 419-433. https://doi.org/10.1080/00207659.2020.1802141

Bjørnskov, C. (2003) The happy few: Cross-country evidence on social capital and life satisfaction. Kyklos, 56(1), 3-16. https://doi.org/10.1111/1467-6435.00207

Bjørnskov, C. (2008) Social capital and happiness in the United States. Applied Research Quality Life, 3(1), 43-62. https://doi.org/10.1007/s11482-008-9046-6

Cargan, L. (1981) Singles: an examination of two stereotypes. Family Relations, 30(3), 377-385. https://doi.org/10.2307/584032

Cockrum, J. - White, P. (1985) Influences on the life satisfaction of never-married men and women. Family Relations, 34(4), 551-556. https://doi.org/10.2307/584017

Czibere, I. (2017) A családi állapot és az élettel való elégedettség összefüggései és hatásuka társadalmi integrációra a magyar társadalomban. Szociológiai Szemle 27(1), 30-63.

DePaulo, B.M. - Morris, W.L. (2005) Singles in society and in science. Psychological Inquiry, 16(2-3), 57-83. https://doi.org/10.1207/s15327965pli162\&3_01

Diener, E. - Suh, E.M. - Lukas, R.E - Smith, H.L. (1999) Subjective well-being: three decades of progress. Psychological Bulletin, 125(2), 276-302. https://doi.org/10.1037/0033-2909.125.2.276

Erát, D. (2020) A „koronaválások” jelensége és lehetséges magyarázatai. In Fokasz, N. - Kiss, Zs. - Vajda, J. (szerk.) Koronavírus idején. Replika e-könyv (pp. 151-159). https://replika.hu/sites/default/files/attachedfiles/korona-v5_1.pdf

Ferencz, Z. (2020) Miért okoz nehézséget a korlátozó intézkedések betartása? https://szociologia.tk.mta.hu/uploads/files/FerenczZ_ kockazatok-jarvany-FF.pdf

Füzér, K. (2015) A bizalom társadalomelmélete és a társadalmi tőke szociológiaelmélete. Századvég, 20(78), 5-16.

Füzér, K. (2020) Társadalmi távolságtartás és digitalizáció: reflexiók a társadalmi tókék szempontjából. Socio.hu Társadalomtudományi Szemle, 2(2020), 121-125.

Galvan, V. - Quarleri, J. (2020) An evaluation of the SARS-CoV-2 epidemic 16 days after the end of social confinement in Hungary. GeroScience, 42, 1221-1223. https://doi.org/10.1007/s11357-020-00237-6

Goumenou, M. - Sarigiannis, D. - Tsatsakis, A. - Anesti, O. - Docea, A. O. - Petrakis, D. - Tsoukalas, D. - Kostoff, R. - Rakitskii, V. Spandidos, D. A. - Aschner, M. - Calina, D. (2020) COVID-19 in Northern Italy: An integrative overview of factors possibly influencing the sharp increase of the outbreak (Review). Molecular Medicine Reports, 22(1), 20-32. https://doi.org/10.3892/mmr.2020.11079

Gregor, A. - Fodor, É. - Koltai, J. - Kováts, E. (2020) The impact of COVID-19 on the gender division of childcare work in Hungary. European Societies, 2020, 1-16. https://doi.org/10.1080/14616696.2020.1817522

Gregor, A. - Kováts, E. (2020) Koronajárvány: a gondoskodási válság látványos lelepleződése. In Fokasz, N. - Kiss, Zs. - Vajda, J. (szerk.) Koronavírus idején. Replika e-könyv (pp. 127-133). https://replika.hu/sites/default/files/attachedfiles/korona-v5_1.pdf

Haller, M. - Hadler, M. (2006) How social relations and structures can produce happiness and unhappiness: an international comparative analysis. Social Indicators Research, 75(2), 169-216. https://doi.org/10.1007/s11205-004-6297-y

Hertel, J. - Schütz, A. - DePaulo, B.M. - Morris, W.L. - Stucke, T.S. (2007) She's single, so what? Zeitschrift für Familienforschung, 19(2), 139-158.

Ho, J-H. (2015) The problem group? psychological wellbeing of unmarried people living alone in the Republic of Korea. Demographic Research, 32(47), 1299-1328. https://doi.org/10.4054/demres.2015.32.47

Hradil, S. (1995) Die „Single-Gesellschaft”. München: C.H. Beck Verlag.

Hradil, S. (2003) Vom leitbild zum „leidbild“: singles, ihre veränderte wahrnehmung und der „wandel des wertewandels“. Zeitschrift für Familienforschung, 15(1), 38-54.

Klein, C. (2013) Social Capital or Social Cohesion: What Matters For Subjective Well-Being? Social Indicators Research, 110, $891-911$.

McKee, M. (2020) Learning from success: how has Hungary responded to the COVID pandemic? GeroScience, 42, 1217-1219. https://doi.org/10.1007/s11357-020-00240-x 
Merkely, B. - Szabó, A. J. - Kosztin, A. - Berényi, E. - Sebestyén, A. - Lengyel, C. - Merkely, G. - Karády, J. - Várkonyi, I. - Papp, C. Miseta, A. - Betlehem, J. - Burián, K. - Csóka, I. - Vásárhelyi, B. - Ludwig, E. - Prinz, G. - Sinkó, J. - Hankó, B. - Varga, P. Fülöp, G. Á. - Mag, K. - Vokó, Z. and for HUNgarian COronaVirus-19 Epidemiological Research (H-UNCOVER) investigators (2020) Novel coronavirus epidemic in the Hungarian population, a cross-sectional nationwide survey to support the exit policy in Hungary. GeroScience, 42(4), 1063-1074. https://doi.org/10.1007/s11357-020-00226-9

Molnár, Gy. - Kapitány, Zs. (2014) Miért elégedetlenek annyira a magyarok az életükkel? Közgazdasági Szemle, 61(6), 637-671.

Möhring, K. - Naumann, E. - Reifenscheid, M. - Wenz, A. - Rettig, T. - Krieger, U. - Friedel, S. - Finkel, M. - Cornesse, C. - Blom A. G. (2020) The COVID-19 pandemic and subjective well-being: longitudinal evidence on satisfaction with work and family. European Societies, https://doi.org/10.1080/14616696.2020.1833066

Nelson-Coffey, S. Katherine - Killingsworth, M. - Layous, K. - Cole, S. W. - Lyubomirsky, S. (2019) Parenthood is associated with greater well-being for fathers than mothers. Personality and Social Psychology Bulletin, 45(9), 1378-1390. https://doi.org/10.1177/0146167219829174

Pietromonaco, P. R. - Overall, N. C. (2020) Applying relationship science to evaluate how the COVID-19 pandemic may impact couples' relationships. American Psychologist, Advance online publication. http://dx.doi.org/10.1037/amp0000714

Portela, M. - Neira, I. - Salinas-Jiménez, M. M. (2013) Social Capital and Subjective Wellbeing in Europe: A New Approach on Social Capital. Social Indicators Research, 114, 493-511. https://doi.org/10.1007/s11205-012-0158-x

Prime, H. - Wade, M. - Browne, D. T. (2020) Risk and resilience in family well-being during the COVID-19 pandemic. American Psychologist, 75(5), 631-643. http://dx.doi.org/10.1037/amp0000660631

Radó, M. K. (2019) Tracking the effects of parentshood on subjective well-being: evidence from Hungary. Journal of Happiness Studies, 21(6), 2069-2094. https://doi.org/10.1007/s10902-019-00166-y

Röst, G. - Bartha, F. A. - Bogya, N. - Boldog, P. - Dénes, A. - Ferenci, T. - Horváth, K. J. - Juhász, A. - Nagy, C. - Tekeli, T. - Vizi, Z. Oroszi, B. (2020) Early Phase of the COVID-19 Outbreak in Hungary and Post-Lockdown Scenarios. Viruses 2020, $12,708$. https://doi:10.3390/v12070708

Rövid I. (2020) A gyermeküket egyedül nevelő szülök életkörülményeinek vizsgálata objektiv és szubjektiv mutatók segítségével a magyar cenzusok adatai alapján: Hogyan befolyásolja a párkapcsolat és a gyermeknevelés a szubjektiv jól(I)étet? PhD disszertáció, Pécs. Pécsi Tudományegyetem Demográfia és Szociológia Doktori Iskola. http://pea.lib.pte.hu/handle/pea/23559

Russell, B. S. - Hutchison, M. - Tambling, R. - Tomkunas, A. J. - Horton, A. L. (2020) Initial Challenges of Caregiving During COVID-19: Caregiver Burden, Mental Health, and the Parent-Child Relationship. Child psychiatry and human development, 51(5), 671-682. https://doi.org/10.1007/s10578-020-01037-x

Sarracino, F. (2010) Social capital and subjective well-being trends: Comparing 11 western European countries. The Journal of SocioEconomics, 39(4), 482-517. https://doi.org/10.1016/j.socec.2009.10.010

Scala, A. - Flori, A. - Spelta, A. - Brugnoli, E. - Cinelli, M. - Quattrociocchi, W. - Pammoli, F. (2020) Time, space and social interactions: exit mechanisms for the Covid-19 epidemics. Scientific Reports, 10, 13764. https://doi.org/10.1038/s41598-020-70631-9

Settersten, R. A. - Bernardi, L. - Härkönen, J. - Antonucci, T. C. - Dykstra, P. A. - Heckhausen, J. - Kuh, D. - Mayer, K. U. - Moen, P. - Mortimer, J. T. - Mulder, C. H. - Smeeding, T. M. - van der Lippe, T. - Hagestad, G. O. - Kohli, M. - Levy, R. - Schoon, I. - Thomson, E. (2020) Understanding the Effects of COVID-19 Through a Life Course Lens. Advances in Life Course Research, 2020, 100360. https://doi.org/10.1016/j.alcr.2020.100360

Shapiro, A. - Keyes, C. L. M. (2008) Marital status and social well-being: are the married always better off? Social Indicators Research, 88(2), 329-346. https://doi.org/10.1007/s11205-007-9194-3

Stutzer, A. - Frey, B. S. (2006) Does marriage make people happy, or do happy people get married? The Journal of Socio-Economics, 35(2), 326-347. https://doi.org/10.1016/j.socec.2005.11.043

Szalma, I. - Rékai, K. (2020) Personal and Online Contact during the COVID-19 Pandemic among Nonresident Parents and their Children in Hungary. International Journal of Sociology, 2020, 1-9. https://doi.org/10.1080/00207659.2020.1786635

Teslya, A. - Pham, T. M. - Godijk, N. G. - Kretzschmar, M. E. - Bootsma, M. C. J. - Rozhnova, G. (2020) Impact of self-imposed prevention measures and short-term government-imposed social distancing on mitigating and delaying a COVID-19 epidemic: A modelling study. PLoS Medicine, 17(7): e1003166. https://doi.org/10.1371/journal.pmed.1003166

Tóth, I. Gy. - Hudácskó, Sz. (2020) A koronavírus-járvány társadalmi hatásai a közvélemény-kutatások tükrében. In Kolosi, T. - Szelényi, I. - Tóth, I. Gy. (szerk.) Társadalmi Riport 2020. Budapest: Tárki, 553-572. https://www.tarki.hu/sites/default/ files/2020-10/553_572_Toth_Hudacsko_web.pdf

Utasi, Á. (2008) Éltető kapcsolatok. A kapcsolatok hatása a szubjektiv életminőségre. Budapest: Új Mandátum.

Veenhoven, R (1984). Conditions of Happiness. Dordrecht: Kluwer Academic Publishers Club. https://doi.org/ 10.1007/978-94-009-6432-7 
Verbakel, E. (2012) Subjective well-being by partnership status and its dependence on the normative climate. European Journal of Population, 28(2), 205-232. https://doi.org/10.1007/s10680-012-9257-2

Vokó, Z. - Pitter, J. Gy. (2020) The effect of social distance measures on COVID-19 epidemics in Europe: an interrupted time series analysis. GeroScience, 42, 1075-1082. https://doi.org/10.1007/s11357-020-00205-0 
FÜGGELÉK

4. táblázat. Lineáris regresszió az élettel való szubjektiv elégedettségre párkapcsolati és gyereknevelési státusz szerint

\begin{tabular}{|c|c|c|c|c|c|}
\hline & \multicolumn{5}{|c|}{ Házas, gyermeket nevelők } \\
\hline & \multirow{2}{*}{\multicolumn{2}{|c|}{ B }} & \multirow{2}{*}{ S.E. } & \multicolumn{2}{|c|}{ K. I. $(95 \%)$} \\
\hline & & & & Alsó & Felső \\
\hline Konstans & 8,337 & $* * *$ & 0,017 & 8,304 & 8,370 \\
\hline Nő (Ref.: Férfiak) & 0,013 & $* *$ & 0,004 & 0,006 & 0,021 \\
\hline Életkor & $-0,037$ & $* * *$ & 0,000 & $-0,037$ & $-0,036$ \\
\hline \multicolumn{6}{|l|}{ Lakóhely (Ref.: Budapest) } \\
\hline Megyeszékhely, M.J.V. & $-0,168$ & $* * *$ & 0,006 & $-0,180$ & $-0,156$ \\
\hline Város & $-0,068$ & $* * *$ & 0,006 & $-0,079$ & $-0,057$ \\
\hline Nagyközség, község & $-0,191$ & $* * *$ & 0,006 & $-0,202$ & $-0,179$ \\
\hline \multicolumn{6}{|l|}{ Végzettség (Ref.: Felsőfokú) } \\
\hline Legfeljebb befejezett általános iskola & $-1,055$ & $* * *$ & 0,007 & $-1,069$ & $-1,041$ \\
\hline Középfokú & $-0,361$ & $* * *$ & 0,004 & $-0,370$ & $-0,353$ \\
\hline Ritka rokonlátogatás (Ref.: Gyakori) & $-0,400$ & $* * *$ & 0,005 & $-0,409$ & $-0,390$ \\
\hline Ritka barátlátogatás (Ref.: Gyakori) & $-0,076$ & $* * *$ & 0,005 & $-0,086$ & $-0,066$ \\
\hline Civil szervezeti aktivitás skála & 0,237 & $* * *$ & 0,004 & 0,230 & 0,244 \\
\hline Bizalom skála & 0,259 & $* * *$ & 0,001 & 0,257 & 0,261 \\
\hline \multicolumn{6}{|c|}{ Képes lakóhelyet érintő kérdések befolyásolására (Ref.: Inkább - teljesen egyetért) } \\
\hline Nem - inkább nem & $-0,523$ & $* * *$ & 0,006 & $-0,534$ & $-0,512$ \\
\hline is-is & $-0,469$ & $* * *$ & 0,006 & $-0,480$ & $-0,457$ \\
\hline \multicolumn{6}{|c|}{ Képes települését érintő kérdések befolyásolására (Ref.: Inkább - teljesen egyetért) } \\
\hline Nem - inkább nem & 0,116 & $* * *$ & 0,009 & 0,097 & 0,134 \\
\hline is-is & 0,116 & $* * *$ & 0,009 & 0,098 & 0,134 \\
\hline \multicolumn{6}{|c|}{ Képes az országot érintő kérdések befolyásolására (Ref.: Inkább - teljesen egyetért) } \\
\hline Nem - inkább nem & $-0,240$ & $* * *$ & 0,010 & $-0,259$ & $-0,220$ \\
\hline is-is & $-0,122$ & $* * *$ & 0,010 & $-0,142$ & $-0,101$ \\
\hline Elemszám (súlyozott) & \multicolumn{5}{|c|}{1185422} \\
\hline F-statisztika & \multicolumn{5}{|c|}{$12817,721 * * *$} \\
\hline Korrigált R-négyzet & \multicolumn{5}{|c|}{0,16} \\
\hline
\end{tabular}

Forrás: Mikrocenzus 2016.

Megjegyzés: * $p<0,05 ; * * p<0,01 ; * * p<0,001$. 


\begin{tabular}{|c|c|c|c|c|c|}
\hline & \multicolumn{5}{|c|}{ Élettársi kapcsolat, gyermeket nevelők } \\
\hline & \multirow{2}{*}{\multicolumn{2}{|c|}{ B }} & \multirow{3}{*}{$\begin{array}{c}\text { S.E. } \\
0,030\end{array}$} & \multicolumn{2}{|c|}{ K. I. (95\%) } \\
\hline & & & & Alsó & Felső \\
\hline Konstans & 7,396 & $* * *$ & & 7,336 & 7,455 \\
\hline Nő (Ref.: Férfiak) & 0,121 & $* * *$ & 0,007 & 0,108 & 0,134 \\
\hline Életkor & $-0,022$ & $* * *$ & 0,000 & $-0,023$ & $-0,021$ \\
\hline \multicolumn{6}{|l|}{ Lakóhely (Ref.: Budapest) } \\
\hline Megyeszékhely, M.J.V. & $-0,335$ & $* * *$ & 0,012 & $-0,359$ & $-0,312$ \\
\hline Város & $-0,164$ & $* * *$ & 0,011 & $-0,185$ & $-0,142$ \\
\hline Nagyközség, község & $-0,270$ & $* * *$ & 0,011 & $-0,292$ & $-0,248$ \\
\hline \multicolumn{6}{|l|}{ Végzettség (Ref.: Felsőfokú) } \\
\hline Legfeljebb befejezett általános iskola & $-1,180$ & $* * *$ & 0,012 & $-1,203$ & $-1,156$ \\
\hline Középfokú & $-0,329$ & $* * *$ & 0,010 & $-0,349$ & $-0,308$ \\
\hline Ritka rokonlátogatás (Ref.: Gyakori) & $-0,369$ & $* * *$ & 0,009 & $-0,387$ & $-0,351$ \\
\hline Ritka barátlátogatás (Ref.: Gyakori) & $-0,235$ & $* * *$ & 0,010 & $-0,254$ & $-0,217$ \\
\hline Civil szervezeti aktivitás skála & 0,326 & $* * *$ & 0,009 & 0,308 & 0,344 \\
\hline Bizalom skála & 0,272 & $* * *$ & 0,002 & 0,269 & 0,275 \\
\hline \multicolumn{6}{|c|}{ Képes lakóhelyet érintő kérdések befolyásolására (Ref.: Inkább - teljesen egyetért) } \\
\hline Nem - inkább nem & $-0,704$ & $* * *$ & 0,010 & $-0,724$ & $-0,684$ \\
\hline is-is & $-0,506$ & $* * *$ & 0,011 & $-0,527$ & $-0,484$ \\
\hline \multicolumn{6}{|c|}{ Képes települését érintő kérdések befolyásolására (Ref.: Inkább - teljesen egyetért) } \\
\hline Nem - inkább nem & $-0,049$ & $*$ & 0,019 & $-0,085$ & $-0,012$ \\
\hline is-is & 0,001 & & 0,019 & $-0,036$ & 0,038 \\
\hline \multicolumn{6}{|c|}{ Képes az országot érintő kérdések befolyásolására (Ref.: Inkább - teljesen egyetért) } \\
\hline Nem - inkább nem & 0,274 & $* * *$ & 0,020 & 0,234 & 0,313 \\
\hline is-is & 0,366 & *** & 0,021 & 0,325 & 0,407 \\
\hline Elemszám (súlyozott) & \multicolumn{5}{|c|}{408818} \\
\hline F-statisztika & \multicolumn{5}{|c|}{$4476,022^{* * *}$} \\
\hline Korrigált R-négyzet & \multicolumn{5}{|c|}{0,16} \\
\hline
\end{tabular}

Forrás: Mikrocenzus 2016.

Megjegyzés: ${ }^{*} p<0,05 ;{ }^{* *} p<0,01 ; * * *<0,001$. 


\begin{tabular}{|c|c|c|c|c|c|}
\hline & \multicolumn{5}{|c|}{ Házas, gyermektelenek } \\
\hline & \multirow{2}{*}{\multicolumn{2}{|c|}{ B }} & \multirow{3}{*}{$\begin{array}{c}\text { S.E. } \\
0,031\end{array}$} & \multicolumn{2}{|c|}{ K. I. (95\%) } \\
\hline & & & & \multirow{2}{*}{\begin{tabular}{|c|} 
Alsó \\
8,528 \\
\end{tabular}} & \multirow{2}{*}{$\begin{array}{l}\text { Felsö } \\
8,651 \\
\end{array}$} \\
\hline Konstans & 8,589 & $* * *$ & & & \\
\hline Nő (Ref.: Férfiak) & $-0,137$ & $* * *$ & 0,008 & $-0,154$ & $-0,121$ \\
\hline Életkor & $-0,043$ & $* * *$ & 0,001 & $-0,044$ & $-0,042$ \\
\hline \multicolumn{6}{|l|}{ Lakóhely (Ref.: Budapest) } \\
\hline Megyeszékhely, M.J.V. & 0,020 & & 0,012 & $-0,005$ & 0,044 \\
\hline Város & 0,207 & $* * *$ & 0,011 & 0,185 & 0,229 \\
\hline Nagyközség, község & 0,113 & $* * *$ & 0,012 & 0,090 & 0,137 \\
\hline \multicolumn{6}{|l|}{ Végzettség (Ref.: Felsőfokú) } \\
\hline Legfeljebb befejezett általános iskola & $-1,130$ & $* * *$ & 0,016 & $-1,162$ & $-1,098$ \\
\hline Középfokú & $-0,481$ & $* * *$ & 0,010 & $-0,500$ & $-0,463$ \\
\hline Ritka rokonlátogatás (Ref.: Gyakori) & $-0,217$ & $* * *$ & 0,010 & $-0,237$ & $-0,197$ \\
\hline Ritka barátlátogatás (Ref.: Gyakori) & $-0,191$ & $* * *$ & 0,011 & $-0,212$ & $-0,170$ \\
\hline Civil szervezeti aktivitás skála & 0,118 & $* * *$ & 0,008 & 0,103 & 0,133 \\
\hline Bizalom skála & 0,252 & $* * *$ & 0,002 & 0,248 & 0,256 \\
\hline \multicolumn{6}{|c|}{ Képes lakóhelyet érintő kérdések befolyásolására (Ref.: Inkább - teljesen egyetért) } \\
\hline Nem - inkább nem & $-0,855$ & $* * *$ & 0,012 & $-0,879$ & $-0,831$ \\
\hline is-is & $-0,485$ & $* * *$ & 0,013 & $-0,510$ & $-0,461$ \\
\hline \multicolumn{6}{|c|}{ Képes települését érintő kérdések befolyásolására (Ref.: Inkább - teljesen egyetért) } \\
\hline Nem - inkább nem & 0,100 & $* * *$ & 0,021 & 0,059 & 0,142 \\
\hline is-is & $-0,144$ & $* * *$ & 0,021 & $-0,185$ & $-0,103$ \\
\hline \multicolumn{6}{|c|}{ Képes az országot érintő kérdések befolyásolására (Ref.: Inkább - teljesen egyetért) } \\
\hline Nem - inkább nem & $-0,072$ & $*$ & 0,022 & $-0,116$ & $-0,028$ \\
\hline is-is & 0,031 & & 0,023 & $-0,014$ & 0,077 \\
\hline Elemszám (súlyozott) & \multicolumn{5}{|c|}{231516} \\
\hline F-statisztika & \multicolumn{5}{|c|}{$3324,081^{* * *}$} \\
\hline Korrigált R-négyzet & \multicolumn{5}{|c|}{0,20} \\
\hline
\end{tabular}

Forrás: Mikrocenzus 2016.

Megjegyzés: ${ }^{*} p<0,05 ;{ }^{* *} p<0,01 ; * * p<0,001$. 


\begin{tabular}{|c|c|c|c|c|c|}
\hline & \multicolumn{5}{|c|}{ Élettársi kapcsolatban, gyermektelen } \\
\hline & \multirow{2}{*}{\multicolumn{2}{|c|}{ B }} & \multirow{2}{*}{ S.E. } & \multicolumn{2}{|c|}{ K. I. (95\%) } \\
\hline & & & & Alsó & Felső \\
\hline Konstans & 8,381 & $* * *$ & 0,026 & 8,329 & 8,432 \\
\hline Nő (Ref.: Férfiak) & $-0,043$ & $* * *$ & 0,007 & $-0,056$ & $-0,029$ \\
\hline Életkor & $-0,044$ & $* * *$ & 0,000 & $-0,045$ & $-0,043$ \\
\hline \multicolumn{6}{|l|}{ Lakóhely (Ref.: Budapest) } \\
\hline Megyeszékhely, M.J.V. & $-0,041$ & $* * *$ & 0,010 & $-0,061$ & $-0,022$ \\
\hline Város & 0,019 & $*$ & 0,010 & 0,000 & 0,038 \\
\hline Nagyközség, község & $-0,113$ & $* * *$ & 0,011 & $-0,134$ & $-0,092$ \\
\hline \multicolumn{6}{|l|}{ Végzettség (Ref.: Felsőfokú) } \\
\hline Legfeljebb befejezett általános iskola & $-1,216$ & $* * *$ & 0,013 & $-1,242$ & $-1,190$ \\
\hline Középfokú & $-0,292$ & $* * *$ & 0,008 & $-0,309$ & $-0,275$ \\
\hline Ritka rokonlátogatás (Ref.: Gyakori) & $-0,325$ & $* * *$ & 0,009 & $-0,342$ & $-0,308$ \\
\hline Ritka barátlátogatás (Ref.: Gyakori) & $-0,203$ & $* * *$ & 0,009 & $-0,220$ & $-0,186$ \\
\hline Civil szervezeti aktivitás skála & 0,182 & $* * *$ & 0,009 & 0,166 & 0,199 \\
\hline Bizalom skála & 0,225 & $* * *$ & 0,002 & 0,222 & 0,228 \\
\hline \multicolumn{6}{|c|}{ Képes lakóhelyet érintő kérdések befolyásolására (Ref.: Inkább - teljesen egyetért) } \\
\hline Nem - inkább nem & $-0,755$ & $* * *$ & 0,010 & $-0,775$ & $-0,734$ \\
\hline is-is & $-0,499$ & $* * *$ & 0,011 & $-0,521$ & $-0,478$ \\
\hline \multicolumn{6}{|c|}{ Képes települését érintő kérdések befolyásolására (Ref.: Inkább - teljesen egyetért) } \\
\hline Nem - inkább nem & $-0,133$ & $* * *$ & 0,019 & $-0,171$ & $-0,096$ \\
\hline is-is & $-0,211$ & $* * *$ & 0,019 & $-0,249$ & $-0,173$ \\
\hline \multicolumn{6}{|c|}{ Képes az országot érintő kérdések befolyásolására (Ref.: Inkább - teljesen egyetért) } \\
\hline Nem - inkább nem & 0,232 & *** & 0,020 & 0,193 & 0,272 \\
\hline is-is & 0,281 & $* * *$ & 0,021 & 0,240 & 0,322 \\
\hline Elemszám (súlyozott) & \multicolumn{5}{|c|}{326990} \\
\hline F-statisztika & \multicolumn{5}{|c|}{$4251,527^{* * *}$} \\
\hline Korrigált R-négyzet & \multicolumn{5}{|c|}{0,18} \\
\hline
\end{tabular}

Forrás: Mikrocenzus 2016.

Megjegyzés: * $p<0,05 ; * * p<0,01 ; * * * p<0,001$. 


\begin{tabular}{|c|c|c|c|c|c|}
\hline & \multicolumn{5}{|c|}{ Egyedülálló szülők, élettárs nélkül } \\
\hline & \multirow{2}{*}{\multicolumn{2}{|c|}{ B }} & \multirow{2}{*}{ S.E. } & \multicolumn{2}{|c|}{ K. I. (95\%) } \\
\hline & & & & Alsó & Felső \\
\hline Konstans & 6,627 & $* * *$ & 0,048 & 6,534 & 6,721 \\
\hline Nő (Ref.: Férfiak) & 0,120 & $* * *$ & 0,017 & 0,087 & 0,153 \\
\hline Életkor & $-0,015$ & $* * *$ & 0,001 & $-0,016$ & $-0,013$ \\
\hline \multicolumn{6}{|l|}{ Lakóhely (Ref.: Budapest) } \\
\hline Megyeszékhely, M.J.V. & 0,178 & *** & 0,015 & 0,149 & 0,207 \\
\hline Város & $-0,301$ & $* * *$ & 0,014 & $-0,328$ & $-0,274$ \\
\hline Nagyközség, község & $-0,270$ & $* * *$ & 0,015 & $-0,300$ & $-0,240$ \\
\hline \multicolumn{6}{|l|}{ Végzettség (Ref.: Felsőfokú) } \\
\hline Legfeljebb befejezett általános iska & $-1,042$ & $* * *$ & 0,017 & $-1,075$ & $-1,010$ \\
\hline Középfokú & $-0,657$ & *** & 0,012 & $-0,681$ & $-0,633$ \\
\hline Ritka rokonlátogatás (Ref.: Gyakori) & $-0,150$ & *** & 0,013 & $-0,175$ & $-0,124$ \\
\hline Ritka barátlátogatás (Ref.: Gyakori) & $-0,549$ & $* * *$ & 0,014 & $-0,575$ & $-0,522$ \\
\hline Civil szervezeti aktivitás skála & 0,192 & *** & 0,011 & 0,171 & 0,213 \\
\hline Bizalom skála & 0,341 & $* * *$ & 0,002 & 0,336 & 0,345 \\
\hline \multicolumn{6}{|c|}{ Képes lakóhelyet érintő kérdések befolyásolására (Ref.: Inkább - teljesen egyetért) } \\
\hline Nem - inkább nem & $-0,541$ & $* * *$ & 0,015 & $-0,570$ & $-0,513$ \\
\hline is-is & $-0,373$ & $* * *$ & 0,016 & $-0,404$ & $-0,342$ \\
\hline \multicolumn{6}{|c|}{ Képes települését érintő kérdések befolyásolására (Ref.: Inkább - teljesen egyetért) } \\
\hline Nem - inkább nem & 0,053 & *** & 0,025 & 0,004 & 0,103 \\
\hline is-is & 0,184 & $* * *$ & 0,026 & 0,133 & 0,235 \\
\hline \multicolumn{6}{|c|}{ Képes az országot érintő kérdések befolyásolására (Ref.: Inkább - teljesen egyetért) } \\
\hline Nem - inkább nem & $-0,406$ & $* * *$ & 0,027 & $-0,459$ & $-0,353$ \\
\hline is-is & $-0,424$ & $* * *$ & 0,029 & $-0,481$ & $-0,367$ \\
\hline Elemszám (súlyozott) & \multicolumn{5}{|c|}{231516} \\
\hline F-statisztika & \multicolumn{5}{|c|}{$2928,650^{* * *}$} \\
\hline Korrigált R-négyzet & \multicolumn{5}{|c|}{0,20} \\
\hline
\end{tabular}

Forrás: Mikrocenzus 2016.

Megjegyzés: ${ }^{*} p<0,05 ;{ }^{* *} p<0,01 ;{ }^{* * *} p<0,001$. 


\begin{tabular}{|c|c|c|c|c|c|}
\hline & \multicolumn{5}{|c|}{ Gyermektelen szinglik } \\
\hline & \multirow{2}{*}{\multicolumn{2}{|c|}{ B }} & \multirow{2}{*}{ S.E. } & \multicolumn{2}{|c|}{ K. I. (95\%) } \\
\hline & & & & Alsó & Felső \\
\hline Konstans & 7,503 & $* * *$ & 0,029 & 7,446 & 7,560 \\
\hline Nő (Ref.: Férfiak) & 0,056 & $* * *$ & 0,008 & 0,040 & 0,072 \\
\hline Életkor & $-0,038$ & $* * *$ & 0,001 & $-0,039$ & $-0,037$ \\
\hline \multicolumn{6}{|l|}{ Lakóhely (Ref.: Budapest) } \\
\hline Megyeszékhely, M.J.V. & 0,001 & & 0,010 & $-0,018$ & 0,020 \\
\hline Város & $-0,152$ & $* * *$ & 0,011 & $-0,175$ & $-0,130$ \\
\hline Nagyközség, község & $-0,017$ & & 0,014 & $-0,045$ & 0,010 \\
\hline \multicolumn{6}{|l|}{ Végzettség (Ref.: Felsőfokú) } \\
\hline Legfeljebb befejezett általános iska & $-1,321$ & $* * *$ & 0,018 & $-1,357$ & $-1,285$ \\
\hline Középfokú & $-0,428$ & $* * *$ & 0,009 & $-0,446$ & $-0,411$ \\
\hline Ritka rokonlátogatás (Ref.: Gyakori) & 0,065 & $* * *$ & 0,010 & 0,045 & 0,084 \\
\hline Ritka barátlátogatás (Ref.: Gyakori) & $-0,465$ & $* * *$ & 0,009 & $-0,483$ & $-0,447$ \\
\hline Civil szervezeti aktivitás skála & 0,233 & $* * *$ & 0,008 & 0,218 & 0,247 \\
\hline Bizalom skála & 0,270 & *** & 0,002 & 0,267 & 0,274 \\
\hline \multicolumn{6}{|c|}{ Képes lakóhelyet érintő kérdések befolyásolására (Ref.: Inkább - teljesen egyetért) } \\
\hline Nem - inkább nem & $-0,694$ & $* * *$ & 0,011 & $-0,716$ & $-0,671$ \\
\hline is-is & $-0,501$ & $* * *$ & 0,012 & $-0,526$ & $-0,477$ \\
\hline \multicolumn{6}{|c|}{ Képes települését érintő kérdések befolyásolására (Ref.: Inkább - teljesen egyetért) } \\
\hline Nem - inkább nem & 0,287 & $* * *$ & 0,020 & 0,248 & 0,326 \\
\hline is-is & 0,158 & *** & 0,021 & 0,117 & 0,199 \\
\hline \multicolumn{6}{|c|}{ Képes az országot érintő kérdések befolyásolására (Ref.: Inkább - teljesen egyetért) } \\
\hline Nem - inkább nem & $-0,435$ & $* * *$ & 0,020 & $-0,474$ & $-0,395$ \\
\hline is-is & $-0,387$ & $* * *$ & 0,022 & $-0,430$ & $-0,344$ \\
\hline Elemszám (súlyozott) & \multicolumn{5}{|c|}{257234} \\
\hline F-statisztika & \multicolumn{5}{|c|}{$3857,756^{* * *}$} \\
\hline Korrigált R-négyzet & \multicolumn{5}{|c|}{0,20} \\
\hline
\end{tabular}

Forrás: Mikrocenzus 2016.

Megjegyzés: ${ }^{*} p<0,05 ;{ }^{* *} p<0,01 ;{ }^{* * *} p<0,001$. 